\title{
ŹRÓDLA DO BADAŃ NAD KASATAMI JÓZEFIŃSKIMI W GALICJI (1782-1848) W ARCHIWACH WIEDEŃSKICH
}

\begin{abstract}
Streszczenie
W ramach międzynarodowego, historycznego projektu badawczego pt. Dziedzictwo kulturowe po klasztorach skasowanych na ziemiach dawnej Rzeczypospolitej oraz na Ślasku w XVIII i XIX wieku: losy, znaczenie, inwentaryzacja zrealizowanego w latach 2012-2016 pod kierunkiem prof. Marka Derwicha przeprowadziłem szereg kwerend $\mathrm{w}$ archiwach wiedeńskich w celu identyfikacji oraz obszernego opracowania archiwaliów związanych z kasatą klasztorów i kolegiat w Galicji. Głównym punktem odniesienia badań był obszerny podzespół Stiftungshofbuchhaltung oraz podseria Signatur 102. Stifte und Klöster: Galizien, znajdujące się w zasobach Österreichisches Staatsarchiv. Opracowania tych zbiorów zakończyłem monograficznymi publikacjami. W niniejszym artykule przedstawiam również dalsze zbiory archiwalne, które ze względów czasowych oraz objętości materiału mogłem przejrzeć jedynie wyrywkowo. Są to tzw. akta dot. domen galicyjskich oraz dalsze akta pojezuickie znajdujące się w zasobach Österreichisches Staatsarchiv. Dalsze kwerendy przeprowadziłem w archiwum zakonu Towarzystwa Jezusowego oraz benedyktynów w Wiedniu, których interesujące nas archiwalia przedstawiam. Ponadto nawiązuję w artykule do problematyki badawczej związanej ze strukturą archiwalną, błędami i nieścisłościami w nazewnictwie, a także $\mathrm{z}$ nikłym zainteresowaniem historią centralnej administracji austriackiej oraz nakreślam dezyderaty badawcze. Do nich należy szczególnie brak opracowania dokumentacji domen galicyjskich (duchownych oraz państwowych). Ten nieznany dotąd zasób jest fundamentalnym źródłem historycznym. Wykonane kwerendy są przyczynkiem do pełnego
\end{abstract}

\footnotetext{
* Gregor Ploch - dr historii; archidiecezja berlińska, Greifswald e-mail: gploch@aon.at https://orcid.org/0000-0003-1753-8950
} 
opracowania galicyjskich archiwaliów kościelnych znajdujących się w zbiorach archiwów wiedeńskich.

Słowa kluczowe: kasaty; zakony; Galicja; józefinizm; Austria; kasaty józefińskie w Galicji; historia Kościoła w Galicji w XVIII i XIX w.; Österreichisches Staatsarchiv; Stiftungshofbuchhaltung; centralna administracja nadworna w Wiedniu

\section{Wstęp}

Po I rozbiorze Polski w 1772 r. monarchia Habsburgów utworzyła z przejętych ziem prowincję o nazwie Królestwo Galicji i Lodomerii, potocznie nazywaną odtąd Galicją. Zabór austriacki został rozszerzony po III rozbiorze o Lubelszczyznę i część Małopolski, w tym Kraków. Utworzona Nowa Galicja wytrwała w tej formie jedynie dekadę, w 1809 r. bowiem północna jej część została wcielona przez Napoleona do Księstwa Warszawskiego, a po zakończeniu wojen napoleońskich przyłączona do zaboru rosyjskiego.

Zmiana organizacji państwowej już w pierwszych latach porozbiorowych radykalnie odbiła się na obliczu struktur Kościoła katolickiego na dawnych ziemiach polskich. W 1773 r. rozwiązane zostało Towarzystwo Jezusowe, a po 1782 r. władze austriackie sukcesywnie przejmowały majątek kościelny. Tzw. kasata józefińska nie dotknęła tylko klasztorów i kolegiat traktowanych przez cesarza jako „,niepożyteczne”, ale obejmowała również inne wspólnoty kościelne. W Galicji władze austriackie sporządziły gruntowny inwentarz mienia oraz spis dochodów wszystkich instytucji kościelnych, począwszy od dóbr biskupich i kapituł, a skończywszy na kościołach parafialnych i ich filiach, kaplicach oraz bractwach. Prace te koordynowały centralne wiedeńskie urzędy nadworne przy współpracy Gubernium Galicyjskiego we Lwowie (galizisches Landesgubernium) jako reprezentanta monarchii w prowincji. Zaangażowanie urzędów wiedeńskich nie było ograniczone jedynie do działań w okresie przeprowadzenia kasat. Administracja nadworna do 1848/1849 r. w ramach Funduszu Religijnego kontrolowała dochody i wydatki z przejętych dóbr, a także zarządzała budynkami pokościelnymi oraz sprawowała pieczę nad ludźmi związanymi z instytucjami kościelnymi.

Nie jest zatem zaskoczeniem, że skrupulatnie zarządzana wiedeńska administracja pozostawiła po sobie ogromne zasoby archiwalne, które do połowy XX wieku zostały parokrotnie reorganizowane. Ze względu na fakt, że urzędy nadworne intensywnie korespondowały z Gubernium Galicyjskim, od którego otrzymywały sprawozdania i ekspertyzy, urząd lwowski zgromadził obszerny zbiór dokumentacji. Część z niej zachowała się we Lwowie, ponadto trzeba również uwzględnić kwestię parokrotnej rewindykacji zasobów archiwalnych po 1920 r., którą obszernie opisuje Jerzy Gaul ${ }^{1}$. Jednakże zdecydowana większość dokumentacji dotycząca kasat w Galicji i ich następstw znajduje się w Wiedniu. Ten ogromny zasób archiwalny z jednej strony powinien cieszyć historyków, ponieważ mają podstawę do przeprowadzenia źródłowej kwerendy. Z drugiej strony, ta obfitość sprawia komplikacje, bowiem archiwalia dotychczas nie zostały opracowane, za-

${ }^{1}$ J. Gaul, Polonika w Allgemeines Verwaltungsarchiv w Wiedniu, „Archeion”, 101 (2000) s. $107-$ 128. 
tem są praktycznie nieznane i pomijane w opracowaniach historycznych. Powód tego dezyderatu badawczego jest prozaiczny: ze względu na specyfikę tematu i regionu historycy austriaccy nie zainteresowali się dotąd tymi archiwaliami, natomiast galicyjscy badacze nie podjęli się trudu systematycznego opracowania zasobów, na które trzeba było przeznaczyć wielomiesięczną, intensywną kwerendę.

W polskiej historiografii tylko sporadycznie przedstawiano charakterystykę najważniejszego archiwum wiedeńskiego - Österreichisches Staatsarchiv (Austriackie Archiwum Państwowe, dalej: ÖStA). Opracowanie J. Gaula jest jedyną obszerną prezentacją tej instytucji ${ }^{2}$. Autor koncentruje się w niej na polonikach, przybliża jednak również specyfikę organizacji austriackiego archiwum, którego struktura różni się od polskiej. Interesująca nas tematyka nie jest jednak pogłębiana. Do krótkich opisów struktury archiwum można zaliczyć recenzję Adama Dąbrowskiego 3 . Pewnym przyczynkiem jest też artykuł ks. Bolesława Kumora o kościelnych polonikach w zasobie archiwów wiedeńskich ${ }^{4}$.

W poniższym artykule pominąłem prace badawcze, w których wykorzystano jedynie informacje źródłowe znajdujące się w zasobach ÖStA, a których głównym punktem zainteresowania są archiwalia o charakterze poloników, w tym również o tematyce kościelnej, aczkolwiek galicyjska proweniencja klasztorna odgrywa tu główną rolę ${ }^{5}$. Ważnym postulatem badawczym dla wspomnianej tematyki jest opracowanie historii centralnej administracji nadwornej w Wiedniu, co widoczne jest $\mathrm{w}$ niejednolitym nazewnictwie urzędów wiedeńskich pojawiających się w polskojęzycznej literaturze przedmiotu, co zostanie omówione dalej.

W ramach międzynarodowego, historycznego projektu badawczego pt. Dziedzictwo kulturowe po klasztorach skasowanych na ziemiach dawnej Rzeczypospolitej oraz na Ślasku w XVIII i XIX w.: losy, znaczenie, inwentaryzacja ${ }^{6}$ zrealizowanego w latach 2012-2016 pod kierunkiem prof. Marka Derwicha przeprowadziłem szereg kwerend w różnych archiwach wiedeńskich w celu identyfikacji oraz obszernego opracowania archiwaliów związanych z kasatą klasztorów i kolegiat w Galicji. Skupiłem się na następujących zbiorach i archiwach:

a) Podzespół „Stiftungshofbuchhaltung”: Allgemeines Verwaltungsarchiv (ÖStA);

b) Podseria „Signatur 102. Stifte und Klöster: Galizien”: Allgemeines Verwaltungsarchiv (ÖStA);

${ }^{2}$ Polonika w Austriackim Archiwum Państwowym [Polonica im Österreichischen Staatsarchiv] 1772-1918, oprac. J. Gaul, Warszawa 2003.

${ }^{3}$ A. Dąbrowski, [rec.]: Anne-Gaëlle Benard, Guide Des Archives Nationales Autrichiennes à L'usage Du Lecteur Francophone, , Mitteilungen des Österreichischen Staatsarchivs”, Inventare 1, Wien 1995, Herausgegeben von der Generaldirektion, ss. 186, „Archeion”, 97 (1997) s. 213-216.

${ }^{4}$ B. Kumor, Ważniejsze polonika kościelne w Archiwach Państwowych w Wiedniu, „Archiwa, Biblioteki i Muzea Kościelne”, 37 (1978) s. 307-311.

${ }^{5} \mathrm{Z}$ najnowszych zestawów prac sięgających do zasobów archiwum wiedeńskiego por. M. Miławicki, Źródła do dziejów Kościoła ormiańskokatolickiego w Galicji w zbiorach wiedeńskich, „Lehahayer", 6 (2019) s.125-147, tutaj: s. 126, przypis 5-6.

${ }^{6}$ Projekt został sfinansowany w ramach programu Ministra Nauki i Szkolnictwa Wyższego pod nazwą „Narodowy Program Rozwoju Humanistyki” w latach 2012-2016. 
c) Zbiory archiwaliów zebrane w zespole „Domänenakten”: Finanz- und Hofkammerarchiv (ÖStA);

d) Archivum Provinciae Austriae Societatis Iesu (AASI, Wiedeń);

e) Musikarchiv, Stiftsbibliothek im Schottenstift (AT-SCHOTTEN/StiB-MUS, Wiedeń).

W artykule została przedstawiona charakterystyka tych archiwaliów. Opracowanie dwóch pierwszych zbiorów opublikowałem w formie monograficznej w języku niemieckim ${ }^{7}$. Wersje polskojęzyczne są w przygotowaniu ${ }^{8}$. Kwerendy w archiwach zakonu jezuitów (d) oraz benedyktynów (e) zostały zakończone, natomiast opracowanie akt dotyczące galicyjskich domen duchownych (Geistliche Domänen Akten - część grupy wymienionej w podpunkcie c) ograniczyłem jedynie do orientacyjnej weryfikacji jednego kartonu. W ramach badań, ze względów czasowych, zupełnie pominąłem zasoby Kriegsarchiv (Archiwum Wojny) ${ }^{9}$, podporządkowanego ÖStA. Oprócz dokumentów Archiwum Wojny zawiera również mapy, plany i fotografie obiektów wojskowych. Ze względu na fakt, że część budynków klasztornych w Galicji, znajdujących się w stolicach cyrkułów, została przejęta przez wojsko, trzeba uwzględnić powyższe archiwum w dalszych badaniach. Poniższy wykaz archiwaliów wiedeńskich nie jest wyczerpujący, a raczej jest pierwszym etapem do pełnego opracowania zagadnienia.

Artykuł jest podsumowaniem wyników kwerend wykonanych w wiedeńskich archiwach, które zostały opublikowane jedynie w przypadku pierwszych dwóch wyżej wymienionych pozycji. Ze względu na fakt, że monografie te ukazały się drukiem w języku niemieckim i poza granicami Polski, ich dostępność jest ograniczona, również ze względu na barierę językową. Artykuł popularyzuje wspomnianą tematykę przy nakreśleniu istotnych postulatów badawczych i streszczeniu najważniejszych zagadnień. W niemieckiej monografii nie rozwinięto np. problematyki polskojęzycznych pojęć (czy generalnie polskiego stanu badań) dotyczących historii administracji austriackiej. Przedstawiam nowe, nieopublikowane dotąd zagadnienia i postulaty badawcze dotyczące ,akt domen” w Finanzund Hofkammerarchiv / ÖStA oraz archiwaliów galicyjskich zgromadzonych w zasobach archiwum Towarzystwa Jezusowego w Wiedniu (AASI).

${ }^{7}$ G. Ploch, Die josephinischen Klosteraufhebungen in Galizien. Teil 1: Akten des Bestandes "Stiftungshofbuchhaltung” im Österreichischen Staatsarchiv zu Wien, München 2020 oraz tenże, Die josephinischen Klosteraufhebungen in Galizien. Teil 2: Akten der Unterserie "Signatur 102: Stifte und Klöster: Galizien” im Österreichischen Staatsarchiv zu Wien, München 2020.

${ }^{8}$ Krótki opis sumaryczny zbioru klasztornego ukazał się w G. Ploch, Zespół nr 102, Klöster und Stifte: Galizien, w Allgemeines Verwaltungsarchiv oraz wybrane inne archiwalia dotyczace klasztorów i zakonów w Galicji w zbiorach Österreichisches Staatsarchiv, w: Kasaty klasztorów na obszarze dawnej Rzeczypospolitej Obojga Narodów i na Śląsku na tle procesów sekularyzacyjnych w Europie, t. 3: Źródta. Skutki kasat XVIII i XIX w. Kasata w latach 1954-1956, red. M. Derwich, Wrocław 2014, s. $17-46$.

${ }^{9} \mathrm{~W}$ polskiej publicystyce pojawia się również forma „Archiwum Wojenne”. 


\section{Problemy związane z pracami badawczymi}

Badając archiwalia kościelne, trzeba uwzględnić szereg problemów utrudniających kwerendy. Główną kwestię stanowi zapis miejscowości, który zawiera liczne błędy, co jest powszechnie znanym problemem. Dalszym utrudnieniem jest brak $\mathrm{w}$ polskiej historiografii prac naukowych związanych $\mathrm{z}$ historią centralnej administracji nadwornej. Brakuje ujednolicenia w nazewnictwie (głównych) urzędów, co zniechęca badacza, ponieważ w aktach wymieniany jest szereg urzędów, izb i kancelarii, które dotychczas nie zostały opisane w literaturze przedmiotu i nie ma ich polskiego odpowiednika w nazewnictwie. Konieczne jest zatem ujednolicenie nazewnictwa znanych już urzędów i wykreowanie nazw nieznanych (lub nieopisanych) dotąd instytucji, a także przedstawienie ich kompetencji. Kolejnym problemem jest specyfika austriackiej archiwistyki, przez co zakwalifikowanie danych archiwaliów w kategoriach „zespół”, „seria” lub „podseria” nie jest jednoznaczne.

\section{a) Blędne nazewnictwo miejscowości}

W monograficznych opracowaniach zasobów archiwalnych „Stiftungshofbuchhaltung” oraz akt klasztornych (,Signatur 102”) szczegółowo przybliżono ich problematykę, zatem poniżej podane zostaną kluczowe zagadnienia. Największym utrudnieniem identyfikacji poszczególnych placówek są często występujące błędne zapisy miejscowości, szczególnie tych mniej znanych. W zespole „Stiftungshofbuchhaltung" wymieniane są praktycznie wszystkie miejscowości galicyjskie, często z błędami, w których urzędnicy przeprowadzili inwentaryzację instytucji kościelnych. Również w aktach klasztornych, obejmujących bardziej znane miejscowości występują omyłki. Powodem tego była nieznajomość języka polskiego wśród komisarzy państwowych, którzy w trakcie inwentaryzacji i dokumentacji sporządzali na miejscu akta i błędnie zapisywali nazwy. Przeinaczenia te $\mathrm{z}$ biegiem czasu były kopiowane przez archiwistów i zostały przeniesione również do nowoczesnych baz danych. Przykładowe, błędne nazwy miejscowości to m.in.: Bohnszowiecz (zamiast: Bołszowce), Nowosiolski (Nowosiółki), Pilno (Pilzno), Praga (Fraga), Sbaracz (Zbaraż), Szebrczeczyn (Szczebrzeszyn), Szczyricice (Szczyrzyc), Szeszow (Rzeszów), Tomaszowj (Tomaszów Lubelski), Trziana (Trzciana), Zamosz (Zamość), Zawololo (Zawałów) czy Zaywosdze (Zagwóźdź). Weryfikację utrudnia fakt, iż część miejscowości pojawia się w paru wersjach, np. „Christinopel” / „Kristianpol” / „Kristinopel” (Krystynopol); „Blizen” / „Bliszne” / „Polizne” (Blizne). Klasztor bazylianów w Pitryczu podawany jest jako „Petrycze”, „Pytrycz” i „Petrykze”. Mylące są miejscowości o końcówkach „-ice”, „-iec” lub „-ica”; miejscowości zawierające na końcu diakrytykę („ń” podano często jako „-nie” albo „-nia”, końcówka ,-ść” wymieniana jest często jako „-scie”), czy zawierające formę „Monaster” (Monasterzyska / Manasterzyska, Monasterz / Manasterz). Kłopotliwa jest ponadto weryfikacja miejscowości o podobnym brzmieniu, np. Werbiąż / Wierbiąż, Krzywa / Krzywe, Brzeżawa / Brzezawa, Czerniejów / Czerniłów. Problematycznymi są ponadto nazwy złożone, zawierające łacińską formę „,nobilium”, np. Słupiec, Paszowa, Buk, Bukowiec 
czy Bystre. W wielu jednostkach dodano do miejscowości formy „superior” i „inferior", przez co konieczna stała się weryfikacja odpowiedniej formy polskiej (Wyżny / Górny lub Niżny / Dolny). Dokładne studium akt niekoniecznie rozwieje wątpliwości, jeśli jednostka archiwalna zawiera np. jedną kartę, a miejscowość wymieniana jest tylko raz lub dwa, przy tym z deklinowaną formą łacińską, np. Sakolowiensibus, Bilecensibus, Jasinoviensis czy Ulashowzensibus.

Pomijam w tym zestawie dalszą problematykę, którą opisałem w opracowaniach odnośnie do nieścisłości w nazewnictwie zakonów. Szczególnie problematyczne są tu zakony franciszkańskie, które często występują w formie „Franziskaner” i konieczna jest weryfikacja odpowiedniej gałęzi. Również dominikanie obserwanci w Galicji nie zawsze są wymieniani pod tą nazwą.

\section{b) Centralna administracja nadworna, a jej znaczenie dla badań nad historią Galicji}

Historiografia austriacka w XX wieku bardzo obszernie przedstawia historię nadwornej administracji wiedeńskiej. W latach 1907-1971 zostało wydane 14-tomowe dzieło Die österreichische Zentralverwaltung zawierające historyczne opracowanie oraz edycję wybranych źródeł. Ukazały się także inne publikacje pogłębiające tematykę. W moich opracowaniach obszernie przedstawiam tę literaturę i streszczam ten temat $\mathrm{w}$ interesującym nas kontekście ${ }^{10}$. Rozpatrując genezę i przebieg kasat, a także dalsze dzieje do 1848 r. trzeba mieć na uwadze rolę i kompetencje administracji wiedeńskiej, aby zrozumieć działania aparatu państwowego jako jednego organizmu oraz jego poszczególnych urzędów. Tematyka kasat z punktu widzenia historii administracji państwowej jest pomijana przez niemieckojęzycznych historyków, którzy skupiają się jedynie na ideologicznej postawie Józefa II (tzw. ,józefinizmie") czy opisie jego działań. W polskiej (czy ukraińskiej) historiografii tematyka administracji austriackiej jest mało znana, dlatego warto zarysować jej istotne kwestie.

Na początku trzeba uwzględnić kwestię dotyczącą państwowości, co jest niekiedy mylone, w literaturze często bowiem jest mowa o „Austrii”, co może sugerować, że chodzi o odrębne państwo, w przeciwieństwie do „Niemiec”. Kasaty lat 80. XVIII wieku nie obejmowały Świętego Cesarstwa Rzymskiego Narodu Niemieckiego, dlatego Józef II nie wystąpił w roli rzymsko-niemieckiego cesarza. Sekularyzacja dotyczyła tzw. austriackich ziem dziedzicznych (österreichische Erbländer, będących integralną częścią Cesarstwa) wraz z ziemiami korony czeskiej (których królem był cesarz w unii personalnej) i węgierskiej oraz nowo przyłączonych ziem, m.in. Galicji. Józef II panował nad nimi jako arcyksiążę austriacki. Po 1848 r. były one zwane krajami koronnymi (Kronländer). Z tego względu administracja była podzielona. Cesarz Maksymilian stworzył pod koniec XV wieku system kancelaryjny, który po wielu reformach przetrwał do $1848 \mathrm{r}$. Opierał się on na trzech filarach: Radzie Nadwornej Rzeszy (Reichshofrat - najwyższy urząd rządowy i sądowniczy), Kancelarii Nadwornej (Hofkanzlei - odpowiedzialną za egzekwowanie nakazów cesarza) i Kamerze Nadwornej (Hofkammer - odpowie-

${ }^{10}$ Ploch, Klosteraufhebungen 1, s. 5-15 oraz Ploch, Klosteraufhebungen 2, s. 5-16. 
dzialną za finanse państwa). Krótko po wybuchu wojny trzydziestoletniej, w 1620 r. wydzielono z Kancelarii Nadwornej część zajmującą się sprawami wewnątrzpolitycznymi austriackich ziem dziedzicznych - późniejszą Kancelarię Nadworną Austriacką [österreichische Hofkanzlei - w Pradze działała odrębna Nadworna Kancelaria Czeska (Böhmische Hofkanzlei)], natomiast sprawami polityki Cesarstwa zajmowała się odtąd Kancelaria Nadworna Rzeszy (Reichshofkanzlei), której przewodniczył arcybiskup Moguncji w funkcji Arcykanclerza Rzeszy (Reichserzkanzler). W kontekście problematyki poruszonej w artykule skupiono się na administracji austriackich ziem dziedzicznych.

W XVIII i na początku XIX wieku przeprowadzono na ziemiach dziedzicznych i korony czeskiej szereg reform administracyjnych, które w radykalny sposób zmieniły oblicze administracji i zasięg kompetencji nowo utworzonych urzędów. Opisuję to szczegółowo w moich wyżej wspomnianych opracowaniach, dlatego pominę w tym miejscu przebieg tych reform. Trzeba mieć jednak na uwadze te przemiany, w dokumentach bowiem wymieniane są poszczególne urzędy, które wielokrotnie zmieniają nazwę. Dopiero reforma administracyjna przeprowadzona przez cesarza Ferdynanda w marcu 1848 r. na skutek wybuchu rewolucji wprowadziła spokój do burzliwej historii administracji ziem dziedzicznych (od 1804 r. - Cesarstwa Austriackiego). Wadliwy system kancelaryjny został zamieniony na funkcjonujący system ministerialny.

W tym miejscu trzeba zwrócić uwagę na problematykę związaną z polskim nazewnictwem urzędów administracyjnych. Różnorodność form thumaczenia pojawia się już w jednej z głównych i najbardziej znanych kancelarii: Hofkammer, odpowiedzialnej za kwestie fiskalno-skarbowe (od 1848 r. c. k. Ministerstwo Finansów). W literaturze XX-wiecznej używa się formy Nadworna Izba Rozrachunkowa, Nadworna Izba Skarbowa czy Skarb Dworski. Jest to jednak bardzo problematyczne, ponieważ nazwa tejże kancelarii brzmi bardzo podobnie jak liczne Nadworne Izby Obrachunkowe (Staatshofbuchhaltungen - w XIX-wiecznych zbiorach ustaw występuje dla nich polska forma Nadworna Izba Rachunkowa ${ }^{11}$ ) czy zainstalowana przez Marię Teresę instancja kontrolna Hofrechnungskammer (obecna austriacka NIK), którą Henryk Wereszycki przetłumaczył właśnie jako Nadworna Izba Rozrachunkowa ${ }^{12}$. Przenosząc problematykę do teraźniejszości: czy można nadać ministerstwu finansów i NIK tak podobnie brzmiące do siebie nazwy, że łatwo o pomyłkę? Tutaj apeluję o „powrót do korzeni” i zapoznanie się z dwujęzycznymi okólnikami, słownikami czy zbiorami ustaw prowincyjnych dla Królestwa Galicji i Lodomerii z XIX wieku, w których użyto innych nazw. Hofkammer jest tu thumaczona dosłownie jako Kamera Nadworna ${ }^{13}$.

${ }^{11}$ Provinzial-Gesetzsammlung des Königreichs Galizien und Lodomerien für das Jahr 1842 [Zbiór Ustaw prowincyjnych dla Królestwa Galicyi i Lodomeryi z roku 1842], Lwów 1844, s. 266269.

${ }^{12}$ H. Wereszycki, Historia Austrii, Wrocław-Warszawa-Kraków-Gdańsk-Łódź 1986, s. 134135 .

${ }^{13}$ Np. Zbiór Ustaw prowincyjnych 1842, s. 63. Również w słownikach polsko-niemieckich z XIX wieku używano tego terminu, zob. Dokładny niemiecko-polski słownik do podręcznego użycia dla Polaków i Niemców, cz. 1, Poznań-Berlin-Bydgoszcz 1844, s. 719. 
Jak przedstawiają corocznie wydawane schematyzmy państwowe, Kamerze Nadwornej podporządkowane były liczne Nadworne Izby Obrachunkowe (Staatshofbuchhaltungen - w ustawach XIX-wiecznych występowała również forma buchhalterya $a^{14}$ ), które zostały wydzielone w 1765 r. przez Marię Teresę i przyłączone do izby kontrolnej Hofrechnungskammer. Izby te nie są zwykłymi księgowościami w dzisiejszym rozumieniu, miały bowiem uprawnienie do wydawania poleceń, co widać np. w zachowanej korespondencji z Gubernium Galicyjskim. Przekładając na obecną strukturę administracji państwowej, można je porównać do departamentów w ministerstwie finansów, aczkolwiek oczywiście trzeba się odnieść do takich porównań z dużą ostrożnością. Pod względem liczebności personelu izba wojenna była największa. Kwestią do dyskusji pozostaje zagadnienie, czy niemiecką nazwę Staatshofbuchhaltungen tłumaczyć na Nadworne Izby Obrachunkowe, czy może jednak dokładniej na Naczelne Państwowe Urzędy Obrachunkowe? Forma nadworne izby (ob)rachunkowe pojawia się w XIX-wiecznych dwujęzycznych zapisach ustaw dla Galicji, więc pozostanę przy tej pierwotnej nazwie.

Wśród nadwornych izb obrachunkowych najbardziej interesującą jest dla nas Stiftungshofbuchhaltung, po której nazwano cały zespół archiwaliów dotyczący kwestii zarządzania przez państwo majątkiem kościelnym. Izba ta nie doczekała się w historiografii niemieckojęzycznej jakiegokolwiek opracowania, co jest o tyle dziwne, że do 1848/1849 r. nadzorowała majątek kościelny na ziemiach austriackich (poza koroną węgierską). Instytucja ta nie powstała jednak w ramach tzw. reform józefińskich, ale już za czasów Marii Teresy. W schematyzmie państwowym jest po raz pierwszy wzmiankowana w 1765 r. jako $k$. $k$. in Stiftungs=und Städtische Sachen Hof=Buchhalterey, co można przetłumaczyć na: c.k. Urzad Obrachunkowy ds. fundacyjnych i miejskich ${ }^{15}$. W moich opracowaniach przedstawiam rozwój izby według corocznych schematyzmów państwowych. Pierwotnie urząd koordynował pracami świeckich (miejskich) i kościelnych fundacji charytatywnych. Instytucja ta nie była nigdzie wzmiankowana w polskojęzycznych pracach, zatem obrałem tytuł roboczy Nadworna Izba Obrachunkowa ds. fundacji. Nazwę tę przyjąłem - ze względu na brak zapisu tej instytucji w ustawach z tamtego okresu - w oparciu o porównanie z podobnie brzmiąco językowo instytucją - Hofkriegsbuchhaltung, która występuje w ustawach galicyjskich w polskiej formie nadworna wojenna Izba obrachunkowa ${ }^{16}$.

W opracowaniach monograficznych przedstawiam funkcję i kompetencje dalszych izb, urzędów czy komisji nadwornych, które do połowy XIX wieku zajmowały się zarządzaniem majątku kościelnego. Zrozumienie działalności całego aparatu administracji nadwornej jako jednego organizmu jest nieodzownym elementem badań historycznych o stosunkach między państwem a Kościołem. Insty-

${ }^{14}$ Zbiór Ustaw prowincyjnych 1842, s. 64-65, pkt 1 i 3.

${ }^{15}$ Schematismus Derer Kays. Königl. Wie auch Erz=Herzoglichen, Nach dem Alphabet gesezten Instanzien (...), Wien 1763, s. 78-79.

${ }^{16}$ Provinzial-Gesetzsammlung des Königreichs Galizien und Lodomerien für das Jahr 1841 [Zbiór Ustaw prowincyjnych dla Królestwa Galicyi i Lodomeryi z roku 1841], Lwów 1844, s. 280281. 
tucje nadworne przez ponad pół wieku zarządzały przejętym w ramach tzw. reform józefińskich mieniem kościelnym, dlatego konieczne jest zainteresowanie się tymi działaniami również z punktu widzenia historii administracji austriackiej.

\section{c) Specyfika austriackiej struktury archiwalnej}

Trudno porównać strukturę austriackiego systemu archiwalnego do polskiego, o czym pisał już J. Gaul ${ }^{17}$. Specyfika struktury ÖStA zdeterminowana jest przez archiwalia wytworzone w poszczególnych kancelariach, które organizowały swoją dokumentację według własnych kryteriów, zatem trudno porównywać zespoły archiwaliów kościelnych zgromadzonych w tym archiwum. Stiftungshofbuchhaltung to odrębny zespół (Bestand), w którym zebrano akta z licznych części monarchii. Zespół ten jest podporządkowany następującej strukturze: ÖStA [Archiv] - Allgemeines Verwaltungsarchiv [Archivabteilung] - Unterricht und Kultus [Bestandsgruppe] - Stiftungshofbuchhaltung [Bestand]. Według tej struktury akta galicyjskie stanowią podzespół (Teilbestand). Bardziej skomplikowany jest zbiór akt klasztornych („Signatur 102"). Archiwalia te mają następujący porządek: ÖStA [Archiv] - Allgemeines Verwaltungsarchiv [Archivabteilung] - Unterricht und Kultus [Bestandsgruppe] - Alter Kultus [Bestand] - Katholischer Kultus [Teilbestand] - Akten [Serie] - Signatur 102 [Unterserie] - 882-898 [Karton]. W nawiasie podaję strukturę archiwalną (podział obszarów) według oficjalnych wytycznych wiedeńskiego archiwum ${ }^{18}$. Według niej zbiór galicyjskich archiwaliów klasztornych to podseria, składająca się z 17 kartonów (882-898). Według J. Gaula, „nauka i wyznania" (Unterricht und Kultus, występujący jako Bestandsgruppe) to zespół, a „stare wyznania” (Alter Kultus - Bestand) to podzespó ${ }^{19}$.

Odrębną problematykę stanowi archiwistyczna kategoryzacja niemieckiego pojęcia „Karton”, jest ona bowiem niejednoznaczna i różni się w zależności od zbioru sygnaturą i jednostką archiwalną. Pojęcie to opisuje nie tylko papierową skrzynkę, w której przechowywane są mniejsze teczki lub luźno zgromadzone dokumenty. Karton posiada bowiem własną sygnaturę, która jest istotna, aby móc zamówić akta. W przypadku podserii „Signatur 102”, aby skorzystać z archiwaliów, trzeba podać numer poszczególnego kartonu (np. sygnatura: AT-OeStA/AVA Kultus AK Katholisch 885). 17 „kartonów” składa się z 101 jednostek archiwalnych posiadających własną sygnaturę (w wymienionym przypadku „kartonu” 885 jest 11 j.a.). Na marginesie trzeba dodać, iż występujące w nazwie podserii słowo „Signatur” oraz liczba porządkowa „102" nawiązują do starej, XIX-wiecznej sygnatury, która nadal jest wymieniana. W dawnej sygnaturze zamiast „kartonu” używano pojęcia „Faszikel”, który w nowym, aktualnym opisie już nie występuje. Natomiast podzespół „Stiftungshofbuchhaltung” zawiera zarówno fascykuły, jak i kartony. Fascykuł posiada odrębną sygnaturę i składa się z jednego (w większości) lub dwóch kartonów, które również mają odrębną sygnaturę. Zamawiając ak-

${ }^{17}$ Polonika w Austriackim Archiwum Państwowym, s. 13-17 oraz 256-258.

${ }^{18}$ Österreichisches Staatsarchiv. Richtlinien für die Verzeichnung von Archivgut im Österreichischen Staatsarchiv, oprac. L. Auer, Wien [b.r.], s. 4-5.

${ }^{19}$ Polonika w Austriackim Archiwum Państwowym, s. 13-17. 
ta, można zatem podać sygnaturę zarówno fascykułu, jak i kartonu. Różnica ta jest istotna w wypadkach, w których fascykuł składa się z dwóch kartonów. Według drukowanego katalogu zawartość „,kartonów” - teczki zawierające dokumenty lub luźne akta - jest podzielona na jednostki archiwalne. W rzeczywistości często trudno dopasować złożone dokumenty do wymienionych w katalogu jednostek.

Akta dotyczące majątków kościelnych są częścią zbiorów późniejszego ministerstwa finansów: ÖStA - Finanz- und Hofkammerarchiv [Archivabteilung]Neue Hofkammer und Finanzministerium [Bestandsgruppe] - Domänenakten [Bestand] - Geistliche Domänen Akten [Serie] - Galizien 7 [Unterserie] - 870$896[\text { Karton }]^{20}$. Zespół (Bestand) akt dotyczacych domen (Domänenakten) jest podzielony na 10 serii obejmujących m.in. akta majątków świeckich, duchownych czy dokumentacji pojezuickiej.

\section{Krótki opis opracowanych zbiorów archiwalnych}

\section{a) Podzespól „Stiftungshofbuchhaltung”: Allgemeines Verwaltungsar- chiv (ÖStA); sygnatura: AT-OeStA AVA Kultus AK StHB Serie B Fasz. 559-715}

Jednym z najobszerniejszych zbiorów archiwalnych zawierających kościelne akta galicyjskie do 1848/1849 r. to podzespół Stiftungshofbuchhaltung, składający się z ok. 180 kartonów. Sygnatury są nadane fascykułom. Fascykuł obejmuje jeden lub dwa kartony. Zbiór zorganizowany jest w następującym porządku:

- Akta ogólne: fasc. nr 559-567;

- Wykaz majątku i dochodów parafii obrządku rzymskokatolickiego (diecezje: Lwów, Przemyśl i Tarnów) oraz greckokatolickiego (diecezje Lwów i Przemyśl): fasc. nr 568-609;

- Wykaz prebend ufundowanych przy kościołach i kaplicach obrządku rzymskokatolickiego (diecezje: Lwów i Przemyśl) oraz obrządku greckokatolickiego (diecezja lwowska): fasc. nr 610-638;

- Wykaz pojedynczych beneficjów (beneficia simplicia) w rzymskokatolickiej diecezji lwowskiej, przemyskiej i tarnowskiej oraz w greckokatolickiej diecezji lwowskiej i przemyskiej: fasc. nr 639-655;

- Wykaz prebend ufundowanych w ośrodkach należących do bractw (konfraterni): fasc. nr 656-663;

- Wykaz majątku i dochodów parafii obrządku ormiańskiego (oraz zakonu benedyktynek): fasc. nr 664;

- Klasztory męskie obrządku rzymsko- i greckokatolickiego (oraz częściowo klasztory prawosławne): fasc. nr 665-668;

- Klasztory żeńskie: fasc. nr 668;

- Inwentarze kościelne: fasc. nr 669-693;

- Inwentarze męskich zakonów mendykanckich: fasc. nr 694-697;

- Inwentarze żeńskich zakonów mendykanckich: fasc. nr 698;

${ }^{20} \mathrm{~W}$ tej strukturze brakuje podzespołu (Teilbestand). 
- Wykaz majątku i dochodów dóbr stołowych należących do archidiecezji lwowskiej/wykaz majątku i dochodów oraz inwentarz dóbr przemyskiej prepozytury katedralnej: fasc. nr 699;

- Kasa Funduszu Religijnego: fasc. nr 700;

- Dokumentacja likwidacyjna dot. majątku i dochodów bractw religijnych: fasc. nr 701;

- Inwentarze dóbr eksjezuickich: fasc. nr 702-704;

- Dalsze ogólne akta: od fasc. nr 705.

Jak widać po ostatnim punkcie, nie definiuję końcowego fascykułu podzespołu. W katalogu drukowanym kończy się on na numerze 750, jednak od fascykułu 716 zbiór zawiera dokumentację pochodzącą z różnych regionów monarchii, zatem proweniencja galicyjska jest tam marginalna. W opracowaniu monograficznym kończę kwerendę na fascykule 715, do fascykułu 743 przedstawiam jedynie tabelaryczny wykaz sporządzony na podstawie wpisu katalogowego ${ }^{21}$.

Archiwalia są fundamentalnym źródłem dotyczącym historii dziejów kościoła w Galicji od drugiej połowy XVIII wieku do Wiosny Ludów. Dotyczą one wszystkich jednostek kościelnych i zawierają kwestie funkcjonowania placówek z punktu widzenia majątkowego i finansowo-skarbowego. W dokumentacji zachowały się obszerne wykazy i inwentarze majątku ruchomego i nieruchomości, dochodów, wydatków czy spisy personalne zakonów. Akta przedstawiają również plany przeprowadzenia kasat, przygotowane przez urzędy wiedeńskie. Poprzedzają je szczegółowe rozważania - dominujące w dokumentacji stolic cyrkułów - na temat tego, które klasztory mają zostać zlikwidowane, a które zachowane; jak i gdzie osiedlić nienadających się do pracy duszpasterskiej zakonników i zakonnice; które klasztory przekształcić na parafie i jak je wyposażyć personalnie, finansowo i materialnie, a które budynki przeznaczyć na cele administracji, instytucji publicznej, oświaty czy wojska. Te obszerne plany można odtworzyć na podstawie zachowanej korespondencji urzędowej między Wiedniem i Lwowem. Działania te koordynowała odpowiedzialna za politykę wewnętrzną ziem austriackich Kancelaria Nadworna (Czesko-Austriacka, w międzyczasie również Galicyjska - pomijam w tym miejscu parokrotne reformy administracyjne, na skutek których kancelarię nadworną połączono z dalszymi urzędami) oraz odpowiedzialna za kwestie finansowo-skarbowe Nadworna Izba Obrachunkowa ds.fundacji (Stiftungshofbuchhaltung). Obydwie instytucje, regularnie wymieniając się między sobą informacjami, dokładnie przygotowywały plan działania i wysyłały Gubernium Galicyjskiemu obszerne instrukcje, które zawierały również dekrety wykonawcze. Gubernium było odpowiedzialne za wykonanie poleceń przesłanych z Wiednia i informowanie urzędów nadwornych o etapie pracy. Wszystkie te urzędy sporządzały bardzo obszerne sprawozdania z planowanych i wykonanych działań, ponadto bardzo szczegółowo informowały cesarza o aktualnej sytuacji. Szczególnie raporty przesyłane przez Kancelarię Nadworną na ręce monarchy są bardzo dobrym źródłem, na podstawie którego można odtworzyć plany urzędni-

\footnotetext{
${ }^{21}$ Ploch, Klosteraufhebungen 1.
} 
ków i przebieg prac. Sprawozdania mają objętość często kilkudziesięciu stron i opisują stan działań w poszczególnych miejscowościach czy instytucjach. Raporty te są zatytułowane nagłówkiem: ,Allerunterthänigster Vortrag der allertreugehorsamsten Hofkanzley”, co można przetłumaczyć jako: , wszechwierno-poddańcza relacja wszechwierno-postusznej Kancelarii Nadwornej".

Skrupulatność działań przygotowawczych i poprzedzających kasaty widoczna jest w zachowanej korespondencji urzędów wiedeńskich, co szczególnie dotyczy akt ogólnych zgromadzonych w pierwszych fascykułach tego podzespołu. Zarówno kancelaria, jak i izba obrachunkowa przesyłały Gubernium liczne wytyczne odnośnie do sporządzenia inwentarzy majątku i mienia oraz spisu personalnego, przy czym wykazywały niecierpliwość z powodu nierzadkiej opieszałości lwowskiej placówki. Zachowane kopie pism kancelarii przesłanych do Lwowa zawierają upomnienia oraz nakaz przyspieszenia finalizacji prac przygotowawczych, aby nie odwlekać likwidacji instytucji kościelnych. Pisma, a szczególnie protokoły z posiedzeń kancelarii oraz sprawozdania sporządzone dla cesarza pokazują ponadto, w jaki sposób zmieniały się w kancelarii wiedeńskiej plany przemian urbanistycznych w stolicach cyrkułów. Typowano strategicznie znajdujące się budynki kościelne i obradowano, jaką instytucję publiczną w nich umieścić lub przekazać wojsku. Plany zmieniały się ze względu na różne okoliczności. Nierzadko widoczne są odmienne interesy partykularne różnych instytucji państwowych. W przeciwieństwie do kasat pruskich z 1810 r. działania w Galicji były długoletnim procesem trwający w większości do końca lat 80 . XVIII wieku. Najtrudniejsze było skoordynowanie działań mających na celu przesiedlenie zakonników do jednego klasztoru, aby pozyskać pozostałe budynki na cele publiczne. Bardzo obszerna korespondencja przedstawiająca te plany przypomina nieraz tasowanie kart do gry: czy sprowadzić pozostałych franciszkanów konwentualnych z A i B do klasztoru karmelitów bosych w $\mathrm{C}$, a tych przeprowadzić do klasztoru benedyktynek w $\mathrm{D}$, a może jednak inaczej... W pojedynczych wypadkach widać, że przez wiele lat regularnie omawiano kwestię adaptacji obiektu poklasztornego, przez co przebieg kasat był procesem długoletnim i niekiedy zmiennym.

Obszerne inwentarze mienia i majątku, kalkulacje dochodów i wydatków związanych z mieniem ruchomym i nieruchomym, ale też z fundacjami kościelnymi (stypendia mszalne, opłaty, składki i darowizny) dotyczą również struktur diecezjalnych, począwszy od biskupstw i kapituł, a skończywszy na kaplicach i bractwach. Odrębną, często pojawiającą się tematyką są spory prawne wywodzące się ze skomplikowanych relacji własnościowych. Akta zawierają również interpelacje przedstawicieli szlachty czy duchowieństwa w spornych sprawach, które kierowane były do najwyższego kanclerza (Oberster Kanzler, w starszych dokumentach nazywany również Obristenkanzler, sprawującego kierownictwo nad Kancelaria Nadworna) lub bezpośrednio do monarchy. W późniejszych latach korespondencja urzędowa dotyczyła spraw zarządzania przywłaszczonym mieniem i związanym z nim dochodami oraz wydatkami, np. opłatą duchowieństwa z Funduszu Religijnego.

Ramy projektu badawczego dotyczącego kasat klasztorów w Galicji przedstawiły konieczność wytypowania i opisania archiwaliów znajdujących się w zaso- 
bach wiedeńskich wyłącznie o proweniencji klasztornej (do których można zaliczyć kolegiaty). Zlecenie badawcze wyraźnie wykluczało zainteresowanie się dalszymi szczeblami struktur diecezjalnych, tzn. parafiami i ich dependencjami, ponieważ wykraczało to poza zakres ściśle zdefiniowanego celu projektu. $\mathrm{Z}$ tego względu kwerendy nie przeprowadzałem chronologicznie, tylko początkowo skupiałem się na częściach podzespołu zawierających wspomnianą tematykę. Jednak na bardziej zaawansowanym etapie prac badawczych problemem było szczegółowe oddzielenie akt klasztornych od diecezjalnych. W aktach występują dependencje kościelne, przy których nie do końca było pewne, czy jest to proweniencja klasztorna, czy nie. Poza tym część grup archiwaliów jest wymieszana. Zdecydowałem się zatem przejrzeć fizycznie i opracować kompletny podzespół, w związku z tym monografia zawiera wszystkie szczeble kościelne w Galicji. Ze względu na objętość podzespołu i ograniczony czas pracy kwerendalnej zdefiniowałem dwa nadrzędne cele tej pracy:

1) Dokładny opis organizacji archiwaliów w podzespole według fascykułów oraz ich specyfika: grupy tematyczne mają swoistą charakterystykę i są ułożone w porównywalny sposób. Jednostki archiwalne zawierają w odrębnych grupach podobne formularze, protokoły i dalszą korespondencję. Przedstawiam również ogólną zawartość każdego fascykułu. Zestaw ma być ułatwieniem orientacji w składzie archiwalnym i pomocą w odnalezieniu konkretnego tematu.

2) Obszerny wykaz miejscowości, dla których sporządzono odrębną teczkę (jednostkę archiwalną). Jest to zestaw ok. 3800 miejscowości. Wykaz ten nie jest kompletny, ponieważ pomijam miejscowości wymieniane w tekstach sprawozdań czy dalszej korespondencji. Dotyczy to szczególnie akt ogólnych, które omawiają różne miejsca. Opracowanie zawiera na końcu obszerny indeks w celu szybkiego odnalezienia miejscowości.

W związku z powyższym trzeba również opisać, jakich celów nie udało się osiągnąć. Opracowanie nie jest dokładnym inwentarzem akt sporządzonym według norm archiwistyki. Takie założenie nie było uwzględnione w założeniu projektu, ponadto cel ten był niemożliwy do spełnienia ze względu na objętość akt i ograniczony czas badawczy. Dlatego też skoncentrowałem się na wytypowaniu miejscowości, które posiadały swoje jednostki archiwalne bądź były obszernie opracowane w dokumentacji, a nie były jedynie wzmiankowane. Szczególnie akta ogólne, czyli pierwsze fascykuły, zostały przeze mnie ogólnie uwzględnione. W większości wypadków przedstawiam zawartość fascykułów i podaję jedynie orientacyjnie objętość poszczególnych akt. Podkreślam zatem konieczność dokładnego przebadania tych akt w dalszych kwerendach.

\section{b) Podseria „Signatur 102. Stifte und Klöster: Galizien”: Allgemeines Verwaltungsarchiv (ÖStA); sygnatura: AT-OeStA/AVA Kultus AK Katholisch 882-898}

Znacznie mniejszym zbiorem archiwalnym jest licząca 17 kartonów podseria obejmująca akta poklasztorne. Jest to jedynie niecałe $10 \%$ objętości podzespołu Stiftungshofbuchhaltung. Zbiór obejmuje dokumentację 39 zakonów z 187 miej- 
scowości. Akta ułożone są w 101 jednostkach archiwalnych. Również ta dokumentacja archiwalna zawiera korespondencję urzędów nadwornych wiedeńskich z Gubernium Galicyjskim. Licznie debatowano nad dalszym losem majątku ruchomego i nieruchomego oraz zakonnikami danego klasztoru czy kolegiaty, analizowano możliwość nowego przeznaczenia poszczególnych budynków klasztornych dla celów instytucji administracji publicznej czy wojska, przedstawiano wstępne kalkulacje możliwych dochodów z tytułu pozyskanych obiektów, rozstrzygano spory natury cywilnoprawnej, uwarunkowane skomplikowanym stosunkiem własnościowym na dobrach ziemskich (kwestie dzierżawy, czynszów czy pańszczyzny). Urzędy również koordynowały plany przekształcenia budynków poklasztornych na szkoły, internaty, seminaria i instytucje administracji publicznej. Akta obejmują dekrety wykonawcze zawierające postanowienia, które zakony zostaną skasowane, a które mogą dalej funkcjonować w określonych warunkach.

Wdrażanie w życie postanowień tzw. reform józefińskich skutkowało przeciążeniem pracy administracji nadwornej. Sama przebudowa systemu opieki charytatywnej i społecznej na wszystkich ziemiach austriackich wymagała zaangażowania wielu urzędników i lokalnych społeczeństw oraz powodowała trudności logistyczne. Tak skomplikowane działania, które miały odbyć się w krótkim okresie na terenie całej Galicji, przerastało kompetencję i możliwości Gubernium Galicyjskiego. Ponadto regionalna administracja oraz wojsko rościły sobie w stolicach cyrkułów prawo do zajęcia budynków klasztornych, co też urzędy musiały uwzględnić, dlatego proces przejmowania tych budynków był długoletni.

Również w tym zbiorze archiwalnym nie opracowałem dokładnego inwentarza archiwalnego, lecz opisałem zawartość kartonów, podając jedynie orientacyjnie objętość jednostek. Skoncentrowałem się na podaniu miejscowości i placówek zakonnych, dla których założono kartoteki (jednostki archiwalne). Instytucje wzmiankowane jedynie w tekstach sprawozdań zostały pominięte ${ }^{22}$.

\section{c) Zbiory archiwaliów zebrane w zespole Domänenakten: Finanz- und Hofkammerarchiv (ÖStA) ${ }^{23}$}

Ważnym elementem historii gospodarczej Austrii jest kwestia alienacji domen. Za czasów panowania Marii Teresy nie istniała jeszcze klarowna definicja dobra państwowego (Staatsgut), nieraz trudno bowiem było rozróżnić własność władcy terytorialnego od majątku państwowego. Podjęto jednak pierwsze kroki w celu rejestracji dóbr podlegających administracji państwowej. Hrabia Ludwig von Zinzendorf, prezydent stworzonej przez Marię Teresę izby kontrolnej Hofrechnungskammer (nie mylić z Kamera Nadworna/Hofkammer!), przedstawił pierwszy zarys kompetencji państwowej administracji domen, której zadaniem miało być zarządzanie dobrami należącymi do monarchini lub do bankowej depu-

\footnotetext{
${ }^{22}$ Ploch, Klosteraufhebungen 2.

${ }^{23}$ Według oficjalnej tektoniki archiwalnej zespół składa się z 10 serii. Brak podzespołów (Teilbestand).
} 
tacji ministerialnej (Ministerial-Bancodeputation) ${ }^{24}$. Głównym zadaniem deputacji, założonej w 1704 r. przez cesarza Leopolda, było administrowanie częścią dochodów pochodzących z dóbr kameralnych i akwizycja dewiz dla państwa. Ponadto miała ona nadzór nad założonym w 1706 r. Wiener Stadtbank, który regulował długi państwa i był odpowiedzialny za podatki pośrednie. Deputacja działała do 1782 r. i została rozwiązana przez cesarza Józefa II $^{25}$.

Odręcznym pismem cesarza (Handbillet) z dnia 24 grudnia 1768 r. stworzono centralną administrację dóbr państwowych w ziemiach austriackich i Siedmiogrodzie, podporządkowując ją Kamerze Nadwornej i nadając jej status odrębnego działu. W rezolucji cesarza $\mathrm{z}$ dnia 5 września 1769 r. dodano do tej instancji agendy Banatu i przekształcono na Hofkammer in Banater und Domänenangelegenheiten, jednak już w 1771 r. oddział ten włączono w strukturę Kamery Nadwornej ${ }^{26}$.

Po I rozbiorze Polski dział administracji domen objął również ziemie galicyjskie, przy czym rozbudowano strukturę, wzorując się na koronie czeskiej. W latach 1772-1773 dobrami zarządzała Kancelaria Państwa (Staatskanzlei), a w kolejnych (1774-1776) Kancelaria Nadworna Galicyjska (galizische Hofkanzlei). Po jej rozwiązaniu agendę przejęła Kamera Nadworna.

Administracja domen została w pierwszych dziesięcioleciach swego istnienia (1769-1801) podzielona na odrębne proweniencje. Seria Galizische Hofkommission Akten zawiera trzy kartony dotyczące dóbr zakonu dominikanów w Bohorodczanach (sygnatura: AT-OeStA/FHKA NHK Dom Gal.Hofkoon 216-218). Tematycznie ciekawymi dla nas są również tzw. akta eksjezuickie (Exjesuitenakten) założone po kasacie Towarzystwa Jezusowego w 1773 r. oraz tzw. akta dot. domen duchownych pozyskane po sekularyzacji dóbr kościelnych (Geistliche Domänen Akten). Zbiór akt pojezuickich dotyczących Galicji założony pod tytułem „Galizien und Ausländer (11)” jest mały, liczy bowiem jedynie 5 kartonów (sygnatura: AT-OeStA/FHKA NHK Dom Exjesuiten 509-513). Dokumenty te zostały od początku zgromadzone w zbiorach Kamery Nadwornej. Dołączono do tych archiwaliów dwa dalsze kartony pochodzące z archiwum Kancelarii Nadwornej (sygnatura: AT-OeStA/FHKA NHK Dom Exjesuiten 590-591). Galicyjskie akta pojezuickie liczą zatem siedem kartonów. Archiwalia pojezuickie nie zostały jednak przez mnie uwzględnione w ramach kwerendy.

W latach 80. XVIII wieku stworzono w ramach tzw. kasat józefińskich dział akt domen, w których zgromadzono dokumentację przedstawiającą centralną administrację dóbr i majątku zrzeszonego w tzw. Funduszu Religijnym (Religionsfonds). Jest to seria zawierająca tzw. akta dotyczące domen duchownych (Geistliche Domänen Akten). Dokumentacja obejmowała również Galicję. Podseria skupiająca galicyjskie akta duchowne liczy 27 fascykułów i obejmuje okres od lipca 1788 do grudnia 1800 r. (sygnatura: AT-OeStA/FHKA NHK Dom geistl.D.

${ }^{24}$ Betrachtungen zur Wirtschafts- und Sozialgeschichte: ausgewählte Schriften von Alois Brusatti aus Anlass seines 60. Geburtstages, red. H. Matis, K. Bachinger, H. Koller, Berlin 1979, s. 9092.

${ }^{25}$ B.M. Buchmann, Hof, Regierung, Stadtverwaltung. Wien als Sitz der österreichischen Zentralverwaltung von den Anfängen bis zum Untergang der Monarchie, Wien 2002, s. 48-57.

${ }^{26}$ Betrachtungen, s. 92. 
870-896). Przejrzałem jedynie pierwszy karton tej podserii, dlatego mogę jedynie orientacyjnie opisać zawartość tych akt.

W 1801 r. wszystkie partykularne działy dotyczące administracji domen zostały podporządkowane Kamerze Nadwornej i złączone w jedną grupę o nazwie Galizische und Bukowinaer Staats- und Fondsgüter, co w dowolnym tłumaczeniu można nazwać „dobrami państwowymi i fundacyjnymi Galicji i Bukowiny”. Archiwalia obejmują zatem również dobra i majątek kościelny przejęty przez Fundusz Religijny i podporządkowany skarbowi państwa. Akta te liczą 220 fascykułów i pochodzą z lat 1801-1874 (sygnatura: AT-OeStA/FHKA NHK allg.Dom 1816-2035). Podseria ta jest częścią serii Allgemeine Domänenakten. Ta bardzo obszerna podseria jest nieodzownym źródłem historycznym dla badaczy dziejów Galicji.

Kartony akt dotyczących domen duchownych zawierają protokoły sporządzone przez administrację Funduszu Religijnego lub administracji dóbr państwowych (Staatsgüteradministration) oraz dalszą korespondencję adresowaną do poszczególnych izb obrachunkowych, Kamery Nadwornej czy Kancelarii Nadwornej. Tematyka dokumentacji obejmuje sprawy fiskalno-majątkowe związane z poszczególnymi obiektami, np. zaległości w kwestii odprowadzeniu zysków na konto Funduszu Religijnego czy zaległe należności z tytułu powstałych kosztów, kwestie przejęcia poszczególnych dóbr przez wojsko, alienacje budynków (czy ogólnie licytacje), corocznie sporządzane szacunki dochodowe (dochody preliminaryjne), zasoby kapitałów sztyftowych czy dochody pochodzące z lasów poklasztornych. Dodany jest wykaz protokołów.

\section{d) Archivum Provinciae Austriae Societatis Iesu (AASI, Wiedeń)}

Archiwum Towarzystwa Jezusowego w Wiedniu zostało założone po reaktywacji zakonu w Austrii w $1829 \mathrm{r}$. W zasobach znajdują się m.in. akta proweniencji galicyjskiej. Zakon powrócił do Galicji w 1820 r. Prowincja galicyjska została rozszerzona w 1829 r. o dom w Styrii, przez co zamieniono nazwę na prowincję galicyjsko-austriacką. W kolejnych latach powstały na ziemiach austriackich dalsze placówki zakonne, dlatego w $1838 \mathrm{r}$. zmieniono nazwę prowincji na austriacko-galicyjską.

Ze względu na duże zniszczenie archiwaliów jezuickich po kasacie zakonu w 1773 r. w archiwum wiedeńskim zachowała się ich szczątkowa dokumentacja. Są to jedynie akta pochodzące z XIX wieku. Dokumentacja galicyjska obejmuje następujące pozycje (orientacyjnie podaję jedynie ogólny opis):

- Rękopis pt. Historia Provinciae Galiciensis Soc. Jesu fundato 1820, a Patre Jacobo Condrau ejusdem Societatis Sacerdote conscripta, prawdopodobnie 1848/49 r., 90 s. (w jęz. łac.), sygnatura: Österr. Prov.-1919 I/1.

- Wykaz „Index Domorum et Sociorum universae Societatis Jesu 1844”, dotyczący kolegiów i domów misyjnych w Milatynie, Nowym Sączu, Pieniakach, Staniątkach, Starej Wsi i Tarnopolu, sygnatura: Österr. Prov.-1919 $\mathrm{I} / 1$.

- Szereg dokumentów przedstawiających fakty ramowe dotyczące reaktywacji Towarzystwa w Galicji, korespondencję prowadzoną między Gu- 
bernium Galicyjskim a prowincjałem o. Stanisławem Świętochowskim SJ w Tarnopolu, korespondencję prowadzoną między Gubernium Galicyjskim a komisją nadworną, pisma o. Jakoba Pierlinga SJ oraz dalszą dokumentację urzędową (opinie, sprawy spadkowe, orzeczenia itd.), pisma wiceprowincjała N. Baworowskiego SJ w sprawie gimnazjum w Nowym Sączu, projekt statutu konwiktu szlacheckiego we Lwowie, lata 18251847, sygnatura: Österr. Prov.-1919 I/5.

- 11 listów autorstwa arcyksięcia Ferdynanda Karola Józefa d'Este (gubernatora Galicji), lata 1838-1850, sygnatura: Österr. Prov. bis 1919 I/14.

- Publikację autorstwa prepozyta prowincji, o. Jakoba Pierlinga SJ. pt. Erklärung über die in einem Ministerial-Dekrete vom 7. Mai 1848 enthaltenen Gründe betreffs der Aufhebung der Gesellschaft Jesu in den $k . k$. österreichischen Staaten, Innsbruck 1848, 14 s. (w jęz. niem.); wykaz majątku domów Towarzystwa Jezusowego na ziemiach austriackich, pismo sporządzone przez Gubernium Galicyjskie, lata 1847-52, sygnatura: Österr. Prov. bis 1919 II/3.

\section{e) Archiwum Muzyczne w opactwie benedyktynów pw. Najświętszej Marii Panny od Szkotów w Wiedniu (sygnatura: AT-SCHOTTEN/ StiB-MUS)}

Celem kwerendy przeprowadzonej w Archiwum Muzycznym (Musikarchiv) znajdującego się w zbiorach biblioteki wiedeńskiego opactwa benedyktyńskiego (Stiftsbibliothek im Schottenstift) było udzielenie odpowiedzi, w jaki sposób zostało zorganizowane stosunkowo młode archiwum i czy w zasobach znajdują się materiały wskazujące na powiązania z klasztorną tradycją muzyczną na interesującym nas terenie dawnej Rzeczypospolitej (oraz Śląska). Większość zachowanej do dziś kompozycji muzycznych przechowywanych w zbiorach opactwa to ok. 2500 rękopisów muzycznych pochodzących od początku XVIII wieku oraz ponad 600 druków nut, używanych w liturgii. Kwerenda wykazała jednak brak powiązania $\mathrm{z}$ interesującym nas regionem.

\section{Podsumowanie}

Wiedeńskie zasoby archiwalne kryją bezcenne źródła dotyczące historii Kościoła katolickiego w Galicji, związane z kasatami józefińskimi i ich następstwami. Ze względu na ich obszerność nie zostały jeszcze opracowane i są praktycznie nieznane wśród historyków zajmujących się Galicją. Przebadane przeze mnie dwa zbiory kościelne są pierwszym przyczynkiem do poznania tych zasobów. Ponadto przedstawiłem dalszą dokumentację galicyjską, którą sprawdziłem jedynie wyrywkowo. Największe wyzwanie stanowi weryfikacja zespołu akt domen wraz z ich podrzędnymi seriami. Kompletne opracowanie tego zespołu jest wielomiesięcznym lub nawet wieloletnim wyzwaniem, które można zrealizować jedynie w formie odrębnego projektu badawczego. Natomiast ze względu na fakt, że galicyjskie akta pojezuickie znajdujące się w zasobach Österreichisches Staatsar- 
chiv oraz archiwum Towarzystwa Jezusowego w Wiedniu stanowią małą ich część, systematyczna weryfikacja tych archiwaliów nie jest zbytnio pracochłonna.

\section{REFERENCES / BIBLIOGRAFIA}

Buchmann Bertrand Michael, Hof, Regierung, Stadtverwaltung. Wien als Sitz der österreichischen Zentralverwaltung von den Anfängen bis zum Untergang der Monarchie, Wien 2002.

Dąbrowski Adam, [rec.]: Anne-Gaëlle Benard, Guide Des Archives Nationales Autrichiennes à L'usage Du Lecteur Francophone, "Mitteilungen des Österreichischen Staatsarchivs", Inventare 1, Wien 1995, Herausgegeben von der Generaldirektion, ss. 186, „Archeion”, 97 (1997) s. 213-216.

Dokładny niemiecko-polski słownik do podręcznego użycia dla Polaków i Niemców, cz. 1, oprac. J.T. Trojański, Poznań-Berlin-Bydgoszcz 1844.

Gaul Jerzy, Polonika w Allgemeines Verwaltungsarchiv w Wiedniu, „Archeion”, 101 (2000) s. 107-128.

Kasaty klasztorów na obszarze dawnej Rzeczypospolitej Obojga Narodów i na Ślasku na tle procesów sekularyzacyjnych w Europie, t. 3: Źródta. Skutki kasat XVIII i XIX w. Kasata w latach 1954-1956, red. M. Derwich, Wrocław 2014.

Kumor Bolesław, Ważniejsze polonika kościelne w Archiwach Państwowych $w$ Wiedniu, „Archiwa, Biblioteki i Muzea Kościelne”, 37 (1978) s. 307-311.

Betrachtungen zur Wirtschafts- und Sozialgeschichte: ausgewählte Schriften von Alois Brusatti aus Anlass seines 60. Geburtstages, red. H. Matis, K. Bachinger, H. Koller, Berlin 1979.

Miławicki Marek, Źródła do dziejów Kościoła ormiańskokatolickiego w Galicji w zbiorach wiedeńskich, „Lehahayer”, 6 (2019) s.125-147.

Österreichisches Staatsarchiv. Richtlinien für die Verzeichnung von Archivgut im Österreichischen Staatsarchiv, oprac. L. Auer, Wien [b.r.].

Ploch Gregor, Die josephinischen Klosteraufhebungen in Galizien. Teil 1: Akten des Bestandes "Stiftungshofbuchhaltung" im Österreichischen Staatsarchiv zu Wien, München 2020.

Ploch Gregor, Die josephinischen Klosteraufhebungen in Galizien. Teil 2: Akten der Unterserie “Signatur 102: Stifte und Klöster: Galizien” im Österreichischen Staatsarchiv zu Wien, München 2020.

Ploch Gregor, Zespót nr 102, Klöster und Stifte: Galizien, w Allgemeines Verwaltungsarchiv oraz wybrane inne archiwalia dotyczace klasztorów i zakonów w Galicji w zbiorach Österreichisches Staatsarchiv, w: Kasaty klasztorów na obszarze dawnej Rzeczypospolitej Obojga Narodów i na Ślasku na tle procesów sekularyzacyjnych w Europie, t. 3: Źródła. Skutki kasat XVIII i XIX w. Kasata w latach 1954-1956, red. M. Derwich, Wrocław 2014, s. 17-46.

Polonika w Austriackim Archiwum Państwowym [Polonica im Österreichischen Staatsarchiv] 1772-1918, oprac. J. Gaul, Warszawa 2003.

Provinzial-Gesetzsammlung des Königreichs Galizien und Lodomerien für das Jahr 1841 [Zbiór Ustaw prowincyjnych dla Królestwa Galicyi i Lodomeryi z roku 1841], Lwów 1844. 
Provinzial-Gesetzsammlung des Königreichs Galizien und Lodomerien für das Jahr 1842 [Zbiór Ustaw prowincyjnych dla Królestwa Galicyi i Lodomeryi z roku 1842], Lwów 1844.

Wereszycki Henryk, Historia Austrii, Wrocław-Warszawa-Kraków-Gdańsk-Łódź 1986.

\section{DIE JOSEPHINISCHEN KLOSTERAUFHEBUNGEN IN GALIZIEN UND DEREN FOLGEN IM SPIEGEL DER WIENER ARCHIVE. EIN BEITRAG ZUR HISTORISCHEN GALIZIENFORSCHUNG IN DEN JAHREN 1782-1848}

\section{Zusammenfassung}

Im Rahmen des internationalen historischen Forschungsprojektes unter dem Titel Das Kulturerbe der aufgehobenen Klöster auf dem Gebiet der früheren Königlichen Republik der polnischen Krone und des Großfürstentums Litauen sowie Schlesiens im 18. und 19. Jahrhundert: Schicksal, Bedeutung, Inventarisierung, das in den Jahren 2012-2016 durchgeführt wurde, an der Universität Breslau (Wrocław) angesiedelt war und von Prof. Dr. Marek Derwich geleitet wurde, habe ich eine Reihe von Wiener Archivbeständen auf Archivalien galizischer Kirchenprovenienz erforscht und ausgewertet. Der Schwerpunkt der Untersuchungen wurde auf zwei Archivsammlungen des Allgemeinen Verwaltungsarchives im Österreichischen Staatsarchiv zu Wien gelegt: auf galizische Akten im Bestand Stiftungshofbuchhaltung sowie auf die Unterserie Signatur 102: Stifte und Klöster: Galizien. Beide Forschungsarbeiten wurden mit jeweils einer Monographie abgeschlossen. Im untenstehenden Artikel werden darüber hinaus weitere Archivbestände präsentiert, die aufgrund der eingeschränkten Forschungszeit und der Fülle an zu untersuchendem Material nur oberflächlich gestreift werden konnten. Dazu gehören die Galizischen Domänenakten (samt Geistlichen Domänenakten) und Exjesuitenakten im Bestand des Finanz- und Hofkammerarchivs (ÖStA). Weitere Forschungsarbeiten wurden im Archiv der Österreichischen Provinz der Gesellschaft Jesu und im Musikarchiv des Schottenstiftes durchgeführt. Die Bestände dieser beiden Wiener Archive werden in diesem Artikel nur zusammenfassend vorgestellt. Im vorliegenden Artikel wird zudem auf die grundsätzliche Problematik eingegangen, die gerade mit der Erforschung der im Österreichischen Staatsarchiv befindlichen Dokumente zusammenhängen. Dazu gehören fehlerhafte Orts- und teils irreführende Ordenseinträge, aber auch die Tatsache, dass die josephinischen Klosteraufhebungen bisher kaum vor dem Hintergrund der Geschichte der österreichischen Zentralverwaltung und deren einzelner Behörden erforscht worden sind. Zuletzt zeige ich Forschungsdesiderata auf. Dazu gehören gerade die eher unbekannten und nicht aufgearbeiteten Domänenakten, die aufgrund ihrer Größe einer intensiven Erforschung bedürfen. Die Domänenakten sind jedoch für die Erforschung der galizischen Kirchengeschichte fundamental wichtig. Genauso wenig bekannt sind die im ÖStA und im Wiener Jesuitenarchiv befindlichen (Ex-) Jesuitenakten. Da sie jedoch nur einen Bruchteil der Geschichte dieses Ordens darstellen, ist deren Aufarbeitung weniger aufwendig. Der vorliegende Artikel 
erhebt keinen Anspruch auf Vollständigkeit, denn die bisher erfolgten Forschungstätigkeiten stellen lediglich einen ersten Beitrag zu einer (hoffentlich zukünftig zu erfolgenden) vollständigen Aufarbeitung des Gesamtbestandes aller in Wien befindlichen Archivalien mit galizischer Provenienz dar. Sicherlich sind bei diesem Aufriss weitere (kleinere) Archivbestände übergangen worden. Es wurde darauf hingewiesen, dass etwa die Erforschung des Kriegsarchivs (ÖStA) aus zeitlichen Gründen übergangen wurde.

Schlüsselwörter: Klosteraufhebungen; katholische Ordensgemeinschaften; Josephinismus; Österreich; Josephinische Klosteraufhebungen in Galizien; Kirchengeschichte in Galizien im 18. und 19. Jahrhundert; Österreichisches Staatsarchiv; Stiftungshofbuchhaltung; österreichische Zentralverwaltung

\title{
SOURCES FOR RESEARCH ON THE JOSEPHINE REFORMS IN GALICIA (1782-1848) IN THE VIENNESE ARCHIVES
}

\begin{abstract}
As part of an international, historical research project entitled Cultural heritage of dissolved monasteries in the territories of the former Polish-Lithuanian Commonwealth and in Silesia in the 18th and 19th centuries: fate, significance, inventory carried out in 2012-2016 under the supervision of Prof. Marek Derwich, I conducted a series of queries in the Viennese archives in order to identify and comprehensively study the archives related to the dissolution of monasteries and collegiate churches in Galicia. The main focus of the research was the extensive Stiftungshofbuchhaltung sub-set and the Signatur 102 sub-series. Stifte und Klöster: Galizien, stored in the Österreichisches Staatsarchiv. I finished the elaboration of these collections with monographic publications. In this article, I also present further archival collections, which, due to time constraints and volume of the material, I was only able to view at random. These are the so-called files on Galician domains and other post-Jesuit files found in the Österreichisches Staatsarchiv. I conducted further research in the archives of the Order of the Society of Jesus and the Benedictines in Vienna, whose archives are of interest to us. In addition, in the article, I refer to research issues related to the archival structure, errors and inaccuracies in nomenclature, as well as scarce interest in the history of the Austrian central administration, and I outline research postulates. One of them is the lack of documentation of Galician domains (clergy and state-owned ones). This hitherto unknown resource is a fundamental historical source. The conducted research contributes to the full study of Galician church archives kept in the collections of the Viennese archives.

Keywords: dissolution; orders; Galicia; Josephinism; Austria, archives, Vienna; Josephine dissassinations in Galicia; history of the Church in Galicia in the 18th and 19th centuries; Österreichisches Staatsarchiv; Stiftungshofbuchhaltung; central court administration in Vienna
\end{abstract}

